\title{
HAMPEL GYÖRGY* \\ A vezetői döntés értelmezése, a döntéshozatal szakaszai és támogatása
}

\begin{abstract}
The decision plays an important role among manager activities. Sometimes it is mentioned independently besides other activities, sometimes it appears as part of other managerial functions. Decisions can be examined from several aspects: goodness, utility, expediency, rationality etc. Making a decision means choosing between at least two alternatives. The process is affected by several (logical and psychological) factors and it consists of some constantly recurring steps which cannot be easily separated in practice. It is vital for the modern enterprise leadership to make prompt and successful decisions and to do that, decision support (information) systems are needed. However, mangers should keep in mind that these systems are not to make decisions - hardware and software cannot take on responsibility -, their job is to help to make decisions.
\end{abstract}

\section{Bevezetés}

A publikációmban - a rendelkezésre álló terjedelem keretein belül - igyekszem rövid áttekintést adni arról, hogy a témával foglalkozó szakirodalomban (1) hogyan vélekednek a döntésröl, a döntéshozatal milyen elemeit tekintik fontosnak, (2) a döntés folyamat jellegét hangsúlyozó szerzők milyen tényezőket tekintenek a döntés, a döntéshozatal részének, továbbá (3) a döntéshozatal szakaszaiban milyen információs rendszerekre támaszkodhat a vezető.

\section{A döntés, mint a vezető tevékenységének része}

Vezetéselmélettel foglalkozó kutatók egy részénél a döntés más egyéb vezetési funkciók része: A hagyományos felfogás szerint a vezetői tevékenység a tervezésből, szervezésböl, vezetésből és ellenőrzésből áll. Hittnél a vezetői funkciók: az elképzelés megalkotása, a csapat kialakítása, az értékek tisztázása, helyzet-meghatározás, kommunikálás, képessé tétel, felkészítés, mérés (Hitt-kerék). (Gulyás et al., 2008) Bár ezeknél a csoportosításoknál nem jelenik meg külön elemként, nyilvánvaló, hogy a „döntés” az egyéb funkciók ellátásához nélkülözhetetlen.

Más kutatóknál a döntés - fontossága miatt - különálló funkcióként jelenik meg a vezetői tevékenység elemei között: Célmeghatározás; információ beszerzése, elemzése, továbbitása; döntés; a feladat végrehajtásának és feltételeinek megteremtése; a feladat végrehajtásra való kiadása; a feladat végrehajtásának ellenőrzése. (Berey, Dobos, 1986) Tervezés, szervezés, igazgatás, döntés, koordinálás, ellenőrzés, teljesítményértékelés, tájékozódás és tájékoztatás, toborzás és kiválasztás. (Angyal, 1999) Munkaerỏ biztosítás, képzés, felügyelet, döntéshozatal, motiváció, tanácsadás, kommunikáció. (Kövesi, 2007) Gondolkodás, problémamegoldás, döntéshozatal. A döntés központi szerepet játszik a vezetési folyamatban; a vezetés és a döntés egymástól elválaszthatatlanok. (Simon, 1977) A vezetés fö feladata: döntést kell hozni. (Baracskai, 2004)

\footnotetext{
'Adjunktus - Szegedi Tudományegyetem Mérnöki Kar.
} 
A döntéshozatal aktív szereplöje az ember - szervezeti döntéshozatal esetén a szervezet vezetōje -, aki észlelve a környezete bizonyos problémáit, meg akarja azokat oldani. Egy vezetőnek az általa irányitott szervezet megfelelő müködése érdekében jó döntéseket kell hoznia. A jó döntéshez lényegre tapintó helyzetfeltárásnak és problémamegoldásnak kell megvalósulnia, továbbá a döntéshozónak

- alkalmasnak kell lennie arra, hogy döntsön (döntési készség);

- elkötelezettnek kell lennie;

- hatáskörébe kell tartozzon a probléma, amit a döntéshozatallal meg kell oldania;

- megfelelö mennyiségü megbízható információval kell rendelkeznie;

- a tudomány ismereteit fel kell használnia;

- komplex módon, az összefuiggések figyelembe vételével kell döntenie;

- a döntéseket jól kell idözítenie;

- egyértelmüvé kell tennie a teljesítménymutatókat;

- fontos a gyors és pontos visszacsatolást kell kapnia a döntések végrehajtásáról, illetve a probléma megoldásáról.

(Körmendi, 2006) (Sántáné et al., 2008)

\section{A döntés tudományos megközelítése}

A döntéssel a különböző tudományágak képviselöi foglalkoznak és a szakterületnek megfelelően más-más nézőpontból vizsgálják azt:

- A döntéshozatal filozófiai megközelítése elsősorban azt vizsgálja, hogy egy adott cselekvés, vagy döntés jó-e? A megközelítésben burkoltan benne van az a feltételezés, hogy ismertnek feltételezett helyzet alapján születnek a döntések. Ez a megközelítése egészen a 19. századig megmaradt. Ekkor még feltételezték, hogy hamarosan tökéletes döntések hozhatók, mert a tudomány képes lesz megmagyarázni minden jelenséget. A tudomány eredményei azonban nem igazolták ezt az elvárást. Kialakult a döntések „operatív filozófiája”, mely szerint a döntések jóságának mértéke az, hogy a döntés eredménye mennyire képes kielégíteni a döntéshozó céljait.

- A döntés szociológiai vizsgálatának tárgya a döntés társadalmi feltételei és következményei. A döntések pszichológiai elemzése azokra a viselkedési formákra irányul, amelyek a döntési helyzetekben, az alternatívák választása során jellemzően előfordulnak.

- A közgazdaságtan döntéselméleti megközelítésének alapja a hasznosság. A hasznosságot az emberi igények kielégítésnek képességeként határozzák meg. Ebben a megközelítésben a döntéshozó célja a hasznosság maximalizálása a korlátozott erőforrások figyelembevételével.

- A közgazdaságtudományból kifejlődő praxeológia (cselekvéstudomány) tárgya a racionális cselekvés logikája és a döntési problémát és ebböl a szemszögböl közelíti meg. Az optimális döntések elmélete szerint, ha a döntéshozó ismeri az összes lehetséges cselekvési változatot, biztosan tudja, hogy az egyes cselekvési változatoknak mi lesz az eredménye. Ha biztosan meg tudja állapítani az eredmények preferenciasorrendjét, akkor a legjobb cselekvési változat kiválasztása már könnyü.

- Az adminisztratív modell szerint a lehetséges döntési alternativák kiválasztása során nem az a lényeges, hogy egy eredménynek mekkora a bekövetkezési valószínűsége, vagy értéke, hanem az, hogy a döntéshozó mekkorának észleli azt. Vagyis az számít, hogy mi van a döntéshozó tudatában, hiszen ez határozza meg döntéseit; lényeges szerepe van a döntéshozó elvárásainak és elgondolásainak is. 
- A megerösitő modell az adminisztratív modellböl kiindulva nem tagadja, hogy az embereknek gondolkodnak és vannak elvárásaik, de azt vallja, hogy nem ez alapján kell az emberek döntéseit és viselkedését megmagyarázni. A döntések magyarázatához fel kell tárni azokat a pozitív eredményeket, amelyek a múltban egyes döntések megerösítéséhez vezettek. A döntések akkor nyernek megerősítést, ha a döntéshozó által pozitívan értékelt eredménnyel jártak. A modell szerint azt a viselkedést, vagy magatartást, ami jutalomhoz vezet, megismétlik; míg, amelyek nem vezetnek jutalomhoz, nem ismétlik meg.

- Szintén az adminisztratív modellhez tartozik a kielégitő döntések elmélete. Képviselöi az objektív racionalitás kifejezést használják arra az esetre, amikor a döntéshozó valóban kielégíti a racionális döntéshozatal feltételeit. Ezek a feltételek azonban csak nagyon ritkán teljesülnek, ezért inkább a „korlátozott racionalitás” kifejezés használata lenne helyes. A korlátozott racionalitás elve alapján dolgozták ki a kielégítő döntések elméletét. A korlátozott racionalitás azt jelenti, hogy a döntéshozó a legtöbb döntési helyzetben ,egyszerüsíti a döntési folyamatot azzal, hogy maximalizálás helyett a kielégítő megoldásra törekszik olyan cselekvési változat választásával, amelyik elegendően jó, azaz kielégitő."

(Majorosné, 1983) (Berde, 2003)

Ma elmondható, hogy a „szakirodalmat az optimalizálás elmélete uralja, de a tapasztalatok és a megfigyelések azt mutatják, hogy a gyakorlatban a kielégitő megoldásokra való törekvés dominál." (March, 1994)

\section{A döntés fogalma és fontosabb jellemzői}

„A vállalatoknál az egyes személyek tevékenysége nem korlátozódik csak a munkák végrehajtására. Gyakran többféle cselekvési lehetőség között kell választanunk, vagyis döntenünk kell." $(\mathrm{Hax}, 1968)$

„A döntést felfoghatjuk úgy, mint átalakítások, transzformációk sorozatát. Meghatározott adatokból (a memóriából átvett induló információkból és a döntéselőkészités közben beérkező közlésekböl) kiszámítanak egy eredményt: a döntést." (Kornai, 1971)

„A döntés célirányos emberi választás adott környezetben cselekvési változatok között, ahol a cselekvési változatok a döntési folyamat döntést megelőzỏ szakaszában cselekvési lehetőségként vannak feltárva." (Kindler, 1991)

A döntés központi eleme a választás. A választást a döntéshozó hajtja végre. Az alternatívák és a célok mindig a környezettel való kapcsolatban értelmezhetők. A cél kitűzése mellett szükség van olyan szabályokra, amely a cél szempontjából értékeli az alternatívákat, ezek a döntési kritériumok. (Chikán, 1978)

A döntéshozatal általánosságban olyan választási folyamatnak fogható fel, amely különböző cselekvési lehetőségekre (ill. nem cselekvésre) terjed ki és eredménye a döntés, vagyis valamilyen cselekvési lehetöség melletti elhatározás. A döntéshozatal tartalmának lényege „... annak meghatározása, hogy kell-e valamit tenni, és ha igen, mit kell tenni, mégpedig mikor és milyen sorrendben." (Hanyecz, 1994) A döntés objektív (a valóság behatárolja, determinálja lehetséges cselekvéseinket) és egyben szubjektiv is, hiszen elválaszthatatlanul összekapesolódik a döntéshozó szuibjektumával. (Hanyecz, 1994)

Kacsukné szerint a döntéshozatal „... olyan folyamat, melynek során különböző cselekvési alternativákat dolgozunk ki, majd választunk egyet ezek közül bizonyos cél vagy célok elérése érdekében." (Kacsukné, 2007)

A döntés választást jelent az alternatívák - azaz legalább két lehetőség - közül. A dön- 
tés objektív kényszer; tünete a probléma, forrása pedig a célok és adottságok között fennálló ellentmondás. A döntés mindig jövőorientáltságot fejez ki a jelenben. Maga a tényleges döntés két mozzanatból áll: az alternatívák összehasonlitásából, mérlegeléséből, és a választásból, ítéletből. A döntés legfontosabb ismérve a választás. A választást mindig az adott külső és belö környezet körülményei, objektiv és szubjektív feltételek befolyásolják. (Bögel, 2002)

„A döntésben egy adott helyzet, probléma, vagy feladat olyan értelmü és kötelezö erejü megoldását értjük, amely megfelel a kitüzött céloknak, illetve a várt eredménynek." (Horváth, 2002) Ez a felfogás a döntést egyenlönek ítéli a feladatmegoldással. A döntés azonban nem csak egyszerü választás az adott lehetőségek közül, hanem egy annál sokrétübb folyamat. Informatív jellegü, mert egyesíti a jelenre és a jövöre vonatkozó információkat. $\mathrm{Az}$ információ azonban önmagában nem elegendö. „A döntés az ember cselekvése, aki saját ismeretei szerint megszüri az információkat, súlyozza azokat, majd érdekei és értékrendszere alapján céljainak megfelelöen határoz. A döntés tehát elhatározás valamilyen célok elérése érdekében" (Horváth, 2002) Így a döntés nem csak egy következetes, logikai folyamat, melynek során a döntéshozó az információk felhasználásával következtetéseket von le és határoz, hanem számos pszichológiai tényezöt is tartalmaz, amely ugyanazokból az információkból a döntéshozó szemléletéböl, érdekéből eredően más és más elhatározásra juttatja a döntéshozót. (Horváth, 2002)

A döntés fontosabb jellemzöi Fröhlich szerint: (1) A döntéshozó mindig egy személy, vagy csoport. (2) Mindig választás különbözö cselekvési alternatívák között. (3) Választani csak akkor lehet, ha van miböl. Legalább két cselekvési alternatívának kell léteznie. (4) Kell lennie valamilyen célnak, amihez döntési kritériumok tartoznak. (5) A döntés mindig egy adott környezetben történik, ami behatárolja a cselekvési lehetöségeket. (6) A döntés nem egyszeri cselekvés, hanem egy folyamat része; passziv (információgyüjtő) és aktiv (információelemzö, döntésvégrehajtó) részekből áll. (7) A döntés lehet érzelmi alapú, vagy elemző. Az érzelmi döntésnél a döntéshozó nem tudja, vagy nem akarja megindokolni elemező módon a döntését: „csak”, „,nekem ez így tetszik”, „ezt akarom” stb. Az elemzỏ döntéseknél lényeges, hogy a döntésekhez megfelelő elökészítés tartozzon, ami tényekre épül. (Fröhlich, 2006)

A felsorolt meghatározásokból kiemelve a legfontosabb megállapitásokat, megállapíthatjuk, hogy a döntés:

- probléma, helyzet, vagy feladat megoldására irányul,

- egy vagy több ember választása,

- cselekvési lehetőségek mérlegelése a célok, várt eredmények figyelembe vételével, majd itélet,

- átalakítások, transzformációk sorozata: adatból információ képzése, majd azokból eredményszámítás,

- megszüri és egyesíti a jelenre és jövöre vonatkozó információkat, jövő-orientált,

- nem egyszeri, hanem visszatérö, folyamat jellegü,

- a következetes logika mellett pszichológiai tényezöket is tartalmaz.

\section{A döntéshozatal szakaszai}

Az emberek gyakran hoznak öntudatlanul döntéseket, illetve úgy, hogy közben nincsenek tudatában a döntést kisérỏ folyamatnak. Természeténél fogva nagyon nehéz fogalmilag megragadni a döntéshozatal folyamatát: a bizonytalansági elemek, a tapasztalat és értékítélet, az elvek befolyása és változása, az egyének kiszámíthatatlansága mind olyan tényezők, amik nehézzé teszik a döntéshozatali folyamat leírását. (Torgersen, 1972) (Mérö, 2008) 
A szerzők többsége a döntést nem statikusan, csupán az alternatívák közötti választásra korlátozódva értelmezi, ami csupán egy pillanat alatt bekövetkező agyi tevékenység (ami a tudomány számára még jórészt feltáratlan terület), hanem folyamatnak tekinti. A dinamikus értelmezés során a döntés több lépésböl álló folyamat lesz, amelynek csupán az egyik fontos eleme a ,döntés"-nek nevezett lépés. (Badacsonyi, 2003)

Mivel nem rendelkezünk pontos ismeretekkel arról, hogy az ember valójában hogyan dönt, a döntés során pontosan mi játszódik le az agyban, a döntési folyamat szakaszainak meghatározása mindössze módszertani eszközként szolgálhat.

A döntéshozatal dinamikus, folyamat jellegü értelmezésekor a szakaszolásra több hasonló megoldás létezik. Mindegyikben a döntési variánsok kidolgozása és az ezek közötti választás áll a középpontban. A döntési folyamat a döntést indukáló objektív szükséglettől a meghozott döntés kommunikációjáig, vagy a döntésvégrehajtásig és annak ellenőrzéséig tart. (Révész, 1981)

Badacsonyi szerint a szakaszok: az akaratképzés (döntési helyzet felismerése, döntés előkészítése, alternativák értékelése, döntés); akaratérvényesítés (az utasítás megvalósítása); ellenőrzés (megvalósítás ellenörzése). (Badacsonyi, 2003)

Simon a döntéshozatali folyamat első szakaszát felderítő tevékenységnek, a második szakaszt tervezési tevékenységnek, a harmadik szakaszt kiválasztási tevékenységnek és végül a negyedik szakaszt áttekintési tevékenységnek nevezi. (Simon, 1977) Számos szerző követi Simon szakaszolását, különbség a szerzök között abban van, hogy míg a döntés megelőző szakaszokat a szerzők fontosnak tartják, némelyikük a döntést követő végrehajtást és ellenörzést már nem tekintik a döntési folyamat részének. (Kindler, Kiss, 1981) (Laky, 1982) (Berey, Dobos, 1986) (Bierman et al., 1991) (Bakacsi et al., 1996) (Enyediné, 1997) (Horváth, 2002) (Bőgel et al., 2002) (Roóz, 2007)

A döntéshozatal szakaszai a szakirodalom alapján (Lásd: 1. ábra):

- A döntési helyzet felismerése, a problémakör és a célok meghatározása: A döntéshozó feladata annak megállapítása, hogy az általa irányított rendszer müködése eltér-e a céltól. A problémát az észlelt jelen idejü állapot és egy kívánatos állapot közötti különbség jelenti. A vezető szempontjából kulcsfontosságú a probléma megfogalmazása, mivel ez indítja el a problémamegoldó folyamatot, így egyáltalán nem mindegy, hogy kinek milyen problémájára keres megoldást a szervezet.

- Helyzetfelmérés, az értékelendỏ alternativák halmazának meghatározása: Az információk összegyüjtése és elsődleges csoportosítása.

- Helyzetelemzés, a probléma okainak megállapítása: Az eredményes problémamegoldás érdekében elemzést kell végezni: a jelenlegi helyzetet, a kívánt állapotot és a különbséget is fel kell mérni. Az egyik kulcskérdés: milyen módon szüntessék meg a különbséget. A beavatkozás lehet csupán kompenzáló jellegü, vagy a kiváltó okokat is megszüntető. Fel kell mérni, hogy egyedi, vagy ismétlődő jellegű problémáról van-e szó. Programozható-e a döntés, vagy nem. Azt is el meg kell határozni, hogy a probléma megoldásához milyen vezetési funkcióval kezdjenek hozzá, a vezető milyen típusú szakismeretét mozgósítsa. Az elemzés arra is rávilágíthat, hogy a probléma számos okból megoldhatatlan. Ilyenkor vissza kell térni a problémaazonositás fázisához és újra kell fogalmazni a problémát úgy, hogy a megvalósítást reális célként lehessen kitüzni. 


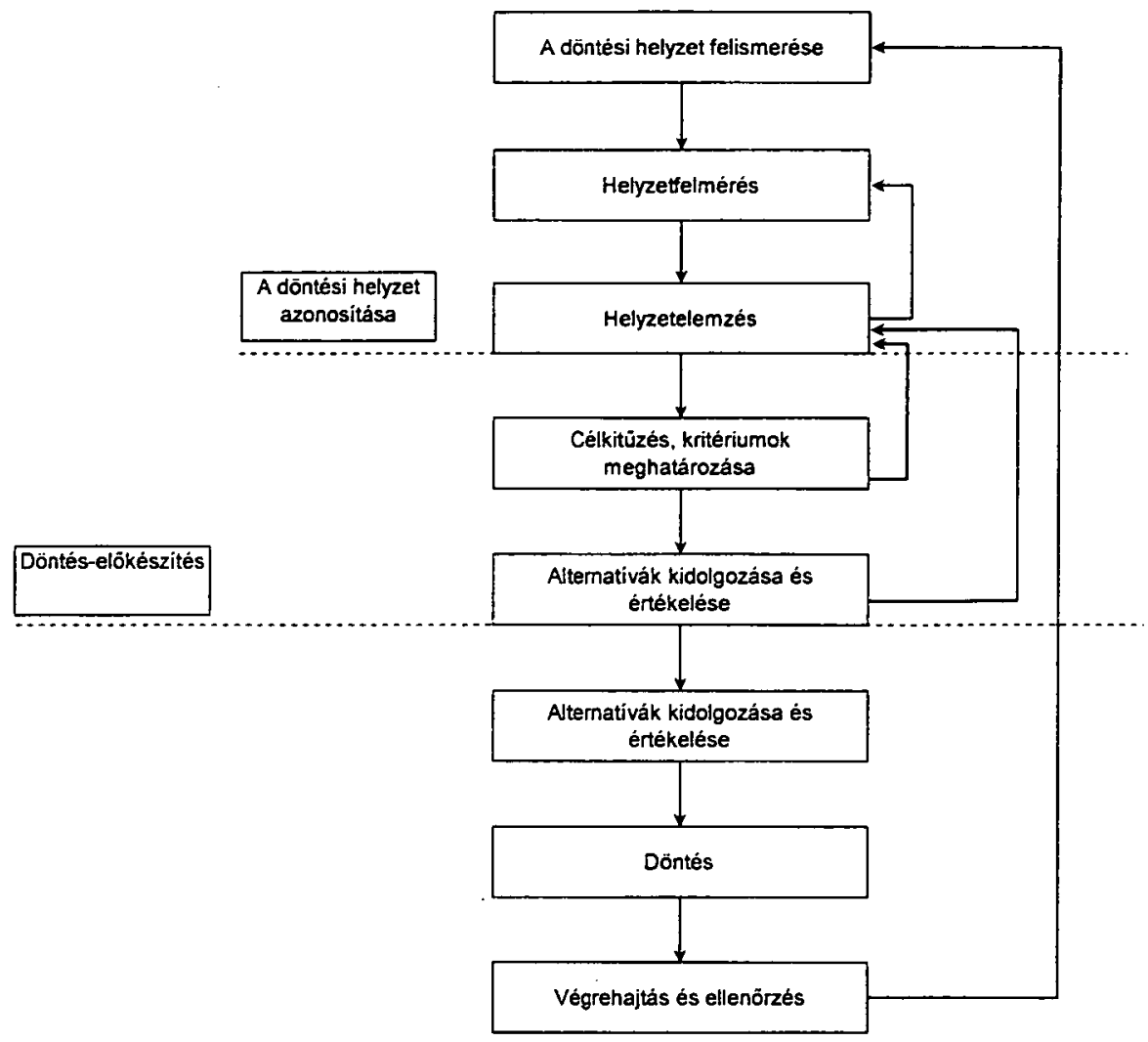

1. ábra. A döntési folyamat szakaszai [Forrás: (Chikán, 1978)]

- Célkitüzés, döntési kritériumok meghatározása: A döntéshozó már rendelkezik annyi információval, hogy a döntési szituáció ismeretében konkrétan megfogalmazza az elérendő célt és így kialakíthatja a cselekvési változatok összehasonlításának szempontját, szabályait, vagyis döntési kritériumokat rendelhet a célhoz.

- Cselekvési lehetöségek kialakitása, értékelése: A cselekvési változatok kidolgozásának alapkérdése, hogy a döntéshozó hogyan jut el a célállapotba. Ha rendelkezik világos céllal, akkor azokat a cselekvési változatokat kell feltárni és megtervezni, amelyek a jelenlegi állapotot célállapottá alakítják.

- Döntés: Ebben a fázisban történik a probléma megoldásának kezdeményezése. Amikor a döntéshozó számára rendelkezésre állnak a cselekvési változatok, azokat értékelték, ismertek a választás következményei és megállapitást nyert, hogy a választási kritériumnak melyik a leginkább megfelelö cselekvés, meg kell hozni a döntést.

- A nyugati kultúra a folyamat legfontosabb elemének a döntést tekinti. A keleti kultúrák másként ítélik meg a döntés szerepét; szerintük a döntés nem változtatja meg a valóságot, a cselekvés a lényeg.

- Végrehajtás: A végrehajtás vezetöi szempontból két feladatot jelent. Egyrészt biztosítani kell a döntés végrehajtásához szükséges feltételeket és eröforrásokat (ember, technikai eszközök, anyag, idő). Másrészt meg kell nyerni azokat, akik részt vesznek a végrehajtásban: felsövezetőket, középvezetöket és a közvetlen végrehajtókat is. 
- Ellenörzés: Ténymegállapitó, értékelő tevékenység; feladata a terv- és tényállapot összehasonlítása, az eltérés megállapítása, az összehasonlítás eredményének értékelése. A hagyományos felfogás szerint az ellenőrzés célja annak megállapitása, hogy egy meghozott döntést jól hajtottak-e végre. Ehelyett inkább azt lenne célszerü vizsgálni, hogy a probléma megoldódott-e. Kiderülhet ugyanis, hogy bár a döntés végrehajtása megfelelö volt, a probléma továbbra is fennáll.

\section{A döntéshozatal támogatása}

A döntéstámogató rendszer szükebb értelmezés szerint olyan interaktív számítógépalapú rendszer, amely nem strukturált probléma megoldása során segíti a döntéshozót az adatok és a modellek felhasználásában. Tágabb értelmezés szerint döntéstámogató rendszernek tekinthető minden számítógépes program, vagy programrendszer, amely egy szervezeten belül segíti a döntéshozatalt. (Sántáné et al., 2008)

A döntéstámogató rendszer célja: felhívni a döntéshozó figyelmét a döntési helyzetre, felismerni a megoldandó problémát, megoldani a döntéshozó (vagy a rendszer) által felismert problémát, kiterjeszteni a felhasználó ismeret-feldolgozó képességét, tanácsokat adni, tényeket, elemzéseket, terveket készíteni a felhasználó számára, elösegíteni a döntéshozó alkotó munkavégzését, tevékenységét, koordinálni a döntéshozók közötti kapcsolatokat. (Holsapple, Whinston, 1996)

Turban és Aronson ennél is részletesebben fogalmazták meg a döntéstámogató rendszer céljait: a rosszul strukturált feladatok megoldásának segítése az emberi ítéletalkotás és a számítógép által nyújtott információk együttes felhasználásával; a döntéshozatali munka segitése a szervezet valamennyi szintjén; az egyéni és a csoportos döntéshozatal támogatása; egymással kapcsolódó, illetve szekvenciális döntések támogatása; a döntési folyamat minden fázisának segítése; különböző stílusú és típusú döntéshozatali folyamatok támogatása; a döntéstámogatás alkalmazkodó megvalósítása; könnyen kezelhető, párbeszédes felhasználói felület kialakitása; a döntéshozatal eredményességének növelése; a döntéshozatali folyamat felügyeletének és ellenörizhetőségének biztosítása; a rendszer könnyü alakíthatósága, módosíthatósága; a modellezési, elemzési módszerek változtathatósága; az adatok széles körü és formátumú elérhetőségének biztosítása. (Turban, Aronson, 1998)

A döntéstámogató rendszer végeredményben „olyan integrált számítógépes eszközök öszszessége, amely döntési modellek, adatbázisok és a döntéshozó saját ítélőképességének segítségével interaktív módon nyújt segítséget nem programozható, vagy részben programozható döntések meghozatalában." (Kacsukné, Kiss, 2007) E rendszerek, nagy mennyiségü adatot feldolgozva, információt szolgáltatnak a vezetőknek rendszeres vagy speciális jelentések formájában. Modellezési képességekkel is rendelkeznek, amelyek segítségével elörejelzéseket, elemzéseket készíthetnek és javaslatokat tesznek. Segítségükkel elérhető a döntés hatékonyságának növelése; minőségi javitásról van szó, ami a jobb döntések meghozatalát támogatja, de nem cél a gyorsabb döntéshozatali folyamat, vagy a döntési teljesítmény fokozása. A döntéstámogató rendszerek nem helyettesítik a döntéshozót, csupán támogatást nyújtanak az egyedi, speciális problémák megoldásában. (Kacsukné, Kiss, 2007)

Cs. Kovács és Sipeki (Cs. Kovács, Sipeki, 1975) a döntés szakaszait és a hozzá kapcsolódó információs rendszer tevékenységeket a következők szerint írja le: Az információs rendszer ún. magatartásszabályai a következők: informál, elökészit, közreműködik, javasol, dönt, végrehajt.

- Az informálás a döntési folyamat kiindulópontja. Az információs rendszernek kevés számú, a vezetés időgazdálkodása szempontjából csak alapvető fontosságú információt szabad eljuttatni a döntéshozóhoz. 
- Az előkészités az információk szervezésével, gyüjtésével, rendszerezésével, elemzésével, feldolgozásával és tárolásával foglalkozik. A folyamat az információ beszerzésével kezdődik és a vezetés döntéseihez szükséges információigény szolgáltatásával fejezödik be.

- A közremüködés azt jelenti, hogy a részfeladatok kimunkálásával kell elősegiteni az elökészitéshez, végrehajtáshoz, javaslattételhez, döntéshez kapcsolódó feladatok megoldását. A közremüködés a döntési folyamat valamennyi fázisában lehetséges.

- A javaslattétel az információáramlásnak az a szakasza, amely a döntéshozatalt közvetlenül megelözi. Növeli a vezető döntési képességét; ezt azzal teszi lehetővé, hogy a döntési lehetőségek közül kiválasztja (és indokolja) azokat, amelyek a vezető által megadott szempontoknak legjobban megfelelnek.

- A döntés a vezetés kritériuma. Nem az információs rendszer, hanem a vezető végzi. A döntés hatékonysága növekszik, ha a vezetöhöz csak a szükséges és pontos információk a kellő időben jutnak el.

- A végrehajtás az információs folyamatnak azt a szakaszát jelenti, amelyben a döntés által meghatározott tevékenység megvalósul. Az ellenőrzés, visszacsatolás célja a döntés helyességének, eredményességének mérése.

A döntéstámogató rendszerek a döntéshozatal szakaszaiban Kacsukné és Kiss, valamint Sảntáné és társai nyomán: (Kacsukné, Kiss, 2007) (Sántáné et al., 2008)

- Az elökészités, feladatmeghatározás és az adatgyüjtés során az adatbázis-kezelö rendszer szolgáltat információkat jelentések és egyedi lekérdezések formájában. Adatbányászat segítségével korábban nem ismert összefüggések ismerhetők fel. A vezetői információs rendszer, a felsővezetői információs rendszer és az on-line elemző feldolgozás felhasználásával megoldható a belső és külső információk folyamatos figyelése, a fontosabb változások korai észlelése. A szakértői rendszerek tanácsot adhatnak a problémák természetét, súlyosságát és a probléma megoldását illetően.

- A tervezés fázisában a rendszer modellezési lehetőségeit használhatják ki a döntéshozók. A döntési alternatívák matematikai, statisztikai modellek, szimulációk segítségével elemezhetők. A döntéstámogató és a szakértő rendszerek, valamint az adatbányászat alternatív lehetőségek előállításával, azok elemzésével, várható következményeinek előrejelzésével nyủjthatnak segítséget. A csoporttámogató rendszerek elösegítik az ötletgenerálást és a konszenzus kialakítását.

- A választási fázisban a rendszerek segithetnek a jó, vagy rossz altemativák kiválasztásában, a „mi lenne, ha”, vagy célérték-kereső típusú elemzésekben és az optimális megoldás kiválasztásában. Konszenzusos döntéshozatalban segíthet a csoporttámogató rendszer. A szakértői rendszer pedig egyes megoldások kívánatosságának kimutatásánál adhat segítséget.

- A megvalósítás során a döntéstámogató és csoporttámogató rendszerek, valamint szakértői rendszerek a magyarázatok és indoklások kidolgozását támogathatják. A megvalósítás során felmerülő problémákra a szakértői rendszerek indoklással ellátott javaslatokat tehetnek.

A döntéstámogató programok előnyei a felkinált szolgáltatások széles választékából és a programok többségének egyszerü kezeléséböl következnek. Megfelelö teljesítményü számítógépek képesek elfogadható időn belül megoldást szolgáltatni. A felkínált sok szolgáltatás azonban veszélyeket is rejthet magában.

A döntéstámogató rendszerek, legyenek azok bármilyen kifinomultak, a legmegalapo- 
zottabb matematikai-statisztikai módszereket, vagy a tudomány más területeinek legújabb eredményeit alkalmazó rendszerek - egyszerủ rutindöntésẹk kivételével - nem pótolhatják a vezetőt, nem vehetik át a vezetőtől a döntést, vagy a döntés következményeivel járó felelösséget.

\section{Irodalom}

Angyal A. (1999): A vezetés mesterfokon. Kossuth Kiadó. Budapest.

Badacsonyi A. (szerk.) (2003): Vezetésmódszertan. Távoktatási jegyzet. Szegedi Tudományegyetem Mezőgazdasági Föiskolai Kar. Hódmezővásárhely.

Bakacsi Gy., Balaton K., Dobák M., Máriás A. (1996): Vezetés-szervezés 2. Aula Kiadó. Budapest.

Baracskai Z., Velencei J. (2004): Követö nélkul nincs vezetö. Myrror Media. Budapest.

Berde Cs. (2003): Vezetéselméleti ismeretek. Campus Kiadó. Debrecen.

Berey A., Dobos I. (1986): Vezetés a gyakorlatban. Közgazdasági és Jogi Könyvkiadó. Budapest.

Bierman, H, Bonini, Ch. P., Hausman, W. H.: (1991): Quantitative Analysis for Business Decisions. Homewood, IL; Boston, MA:Irwin.

Bógel Gy., F. Ható K., Keresztes J., Salamonné H. A., Zárda S. (2002): Szervezési és vezetési ismeretek: elmélet és gyakorlat informatikusoknak. Számalk Kiadó. Budapest.

Chikán A. (1978): Operációkutatás és döntéselmélet II. Müszaki Könyvkiadó. Budapest.

Cs. Kovács F., Sipeki Z. (1975): Vállalati pénzügyi döntések. Tankönyvkiadó. Budapest.

Enyediné M. (1997): Bevezetés a döntéselméletbe. Ligatura Kiadó. Budapest.

Fröhlich Lajos (2006): Rendszerszervezés 2. Oktatási segédlet. Szegedi Tudományegyetem Mérnöki Kar. Szeged.

Gulyás L., Keczer G., Veres L., Turcsányi E., Erdélyi E., Majó Z. (2008): A vezetéstudomány alapjai. Jatepress Szegedi Egyetemi Kiadó. Szeged.

Hanyecz L. (1994): Döntéshozatal. Döntési modellek. Janus Pannonius Tudományegyetem Egyetemi Kiadó. Pécs.

Hax, H. (1968): A döntések koordinálása. Közgazdasági és Jogi Könyvkiadó. Budapest.

Holsapple, C. W., Whinston, A. B.: Decision Support Systems, a Knowledge Based Approach. West Publ. Co., St. Paul. 1996.

Horváth, I. (2002): Közigazgatási szervezés- és vezetéstan. Dialóg Campus Kiadó. Budapest-Pécs.

Kacsukné B. L., Kiss T. (2007): Bevezetés az ủzleti informatikába. Akadémiai Kiadó. Budapest.

Kindler J. (1991): Fejezetek a döntéselméletböl. Aula Kiadó. Budapest.

Kindler J., Kiss R. (1981): Döntéselméleti és módszertani tanulmányok II. Kézirat. Veszprém.

Kornai J. (1971): Anti-equilibrium. Közgazdasági és Jogi Könyvkiadó. Budapest.

Körmendi L., Tóth A. (2006): A Controlling elmélete és gyakorlata. Perfekt Kiadó. Budapest.

Kövesi J. (szerk.) (2007): Menedzsment és vállalkozásgazdaságtan. Typotex Kiadó. Budapest.

Laky T. (1982): Érdekviszonyok a vállalati döntésekben. Közgazdasági és Jogi Könyvkiadó. Budapest.

Majoros B., Radó L., Marasek V., Rozgonyi T., Uszta J. (1983): A vezetöi döntés elmélete és gyakorlata a szakirodalom tükrében. OVK Házinyomda. Budapest.

March, J. G. (1994): A Primer on Desicion Making: How Decisions Happen. The Free Press. New York.

Méró L. (2008): Az elvek csapodár természete. Tericum Konnyvkiadó. Budapest.

Révész B. (1981): A döntés fogalmi meghatározásának néhány problémája. Acta Jur. et Pol. Szegedi József Attila Tudományegyetem. Szeged.

Roóz J. (2007): A menedzsment alapjai. Perfekt Kiadó. Budapest.

Sántáné-Tóth E., Bíró M., Gábor A., Kö A., Lovrics L. (2008): Döntéstámogató rendszerek. Panem Kiadó. Budapest.

Simon, $H$. A. (1977): The New Science of Management Decision. Prentice-Hall. Upper Saddle River, NJ. USA.

Torgersen, P. E., Weinstock, I. T. (1972): Management: an Integrated Approach. Prentice-Hall.

Turban, E., Aronson, J. E.: Decision Support Systems and Intelligent Systems. Prentice-Hall. Upper Saddle River, 5th ed. 1998. 